DOI https://doi.org/10.18551/rjoas.2017-02.11

\title{
HOUSEHOLD ECONOMIC ACTIVITIES OF COASTAL RESOURCE USERS' COMMUNITY IN CENGKRONG COASTAL AREA, PRIGI BAY, TRENGGALEK DISTRICT
}

\author{
Purwanti Pudji ${ }^{\star}$, Susilo Edi, Indrayani Erlinda \\ Department of Fisheries Socio-Economic, Faculty of Fisheries and Marine Sciences, \\ University of Brawijaya, Indonesia \\ *E-mail: pudjipurwanti@gmail.com
}

\begin{abstract}
In one decade, the total area of mangrove forests in Prigi Bay has been declined drastically. Since 2008, replanting or reforestation has been done in the area of mangrove forests on the Cengkrong coast. It means that the development of mangrove forest management could affect the household economic activities in Cengkrong surrounding area. Related to that, this research aims to (1) describe the resource management profile in Cengkrong coastal area (2) explain the household economic activities of the coastal resource users' community in Cengkrong which include productive activities, work outpouring, income-outcome activity as well as a surplus of each household. Replanting mangrove forests on Cengkrong coastal area makes the area of mangrove forests as an ecotourism. This certainly created a productive activity which directly related to mangrove ecotourism such as mud crab cultivation, anadara clam cultivation, mangrove seedlings development, food stalls, boat rentals, and also sanitary facility. This activity is done by a POKMASWAS (Kelompok Masyarakat Pengawas) or community supervisor "Kejung Samudra" and his family. Meanwhile, the productive activities which are performed by the people in the surrounding area include crab farming, fish farming, and food selling along Cengkrong Beach. The work time of POKMASWAS "Kejung Samudra" in average is by 317 workdays per year. Moreover, the income for the member of "Kejung Samudra" is retrieved from boat rentals, parking area management, and sanitary facility which in average is amounted up to IDR 100,000/day until IDR 250,000/day. Furthermore, the business activities of mud crab cultivation could give a profit by IDR $7,933,500 /$ month with the earning ratio of $276,77 \%$. The work outpouring of food stalls in average is 315 workdays per year with the average profit of IDR $9,246,000 /$ year/person. On the other hand, the average work outpouring of crab farming is by 81 workdays per year in which it could generate such income by IDR 22,676,000/year. Then, the work time spent for fish farming is also in 81 workdays per year and earned about IDR $1,920,000$ /year. Therefore, the highest food expenditure on "Kejung Samudra" committee is by IDR $26,460,000$. In addition to the activities in the field of fisheries, the coastal community also engages in the non-fisheries production activity, for example, as farmers or peasants.
\end{abstract}

\section{KEY WORDS}

Replanting mangrove forests, productive activities, the outpouring of work time, household income and expenditure.

Prigi Bay is located in Trenggalek District, East Java in which it is surrounded with southern mountains and merged with the coastal areas. The vegetation which grows in Prigi Bay is the plant that is usually flourishing in mountain areas and blend with mangrove plants in coastal and tidal areas. The area of mangrove plants in Prigi Bay up to now is spread in Damas Beach and Cengkrong Beach. Unfortunately, the area of mangroves in here began to decrease in 1999-2000 where the large-scale reduction of mangrove vegetation occurs mainly in Damas Beach. This reduction had occurred since the Social Forestry activity were implemented, this activity was known as the Collaborative Forest Management Program (PHBM) in 2003 (Susilo et al, 2008).

The replanting activity of mangrove vegetation is conducted since 2008 on both areas such as Cengkrong Beach and Damas Beach. However, the success of the rehabilitation of 
mangrove forests on both coasts is in opposite directions. The condition in Damas Beach is still experiencing a reduction in its mangrove area while in contrast, Cengkrong Beach is in a more stable condition. Furthermore, mangrove forest area in Cengkrong Beach has increased from 42,557 ha to 87,557 ha in 2012. This mangrove rehabilitation is followed by the formation of Community Supervisors (Kelompok Masyarakat Pengawas or POKMASWAS) "Kejung Samudra". Thus, since 2012, the Department of Marine and Fisheries of Trenggalek has introduced the concept of mangrove ecotourism forests by building a bridge over the forest. POKMASWAS "Kejung Samudra" has been designated as a manager in the management of this ecotourism forests. The existence of mangrove forests that have been rehabilitated has impacted the economic activities of the surrounding community.

Good management of mangrove ecosystems will provide economic benefits to the surrounding community. Instead, the destruction of mangrove ecosystems also affected the people which live in the surrounding area. This can be seen in several studies like in Van Hue and Scott (2008), they said that as a result of mangrove destruction due to shrimp farming industry activities, shrimp farmers become poorer and have a lot of debt because their shrimp farming was not successful. The study from Saint-Paul (2006) expresses the relationship between the rural population in Caeté Bay and mangrove ecosystems. The study shows that the preservation of mangrove systems in this region is fundamental to the maintenance of the household quality. Mangroves provide subsistence products for nutrition supply, housing, fuel, as well as commercial products that are able to produce revenue. Further degradation of mangrove forests will create a significant revenue loss for the local population and increase the potential of social conflict.

The survival of communities still depends on the use of forest resources, this statement is also supported by the research of Eleanya et al (2015). Households are involved in many activities with the production of materials that are based on mangrove forests including canoe carving, basket weaving, fish card weaving, snails catching, crabs farming, traditional medicine, fishing, firewood business, and sand collecting. The mangrove forests in Akassa Nigeria island that have become the foundation for the household in its surrounding area are currently experiencing a serious threat on large exploitation.

This research aims to (1) describe the resource management profile in the Cengkrong coast (2) explain the household economic activities of the coastal resource users' community in Cengkrong coast which include production activities, work outpouring, income-outcome activity as well as a household surplus. The results of the research can be used as an evaluation and management model of mangrove forests in the study area as well as an information for the local government in construction its regulation.

\section{MATERIALS AND METHODS OF RESEARCH}

This research was conducted in Cengkrong Coast, Prigi Bay that is already rehabilitated with mangrove plants. The method in this study was adapted from a survey method to describe a systematic and factual account of the current state (Nasir, 2003). The research material used was the mangrove forest ecosystems in Cengkrong Coast with its management institution, community, and their economic activities. The number of respondents in this study was 19 households consisting the member of POKMASWAS "Kejung Samudra" crab farmers, fishers, and sellers along the Cengkrong Beach.

Furthermore, the data of this study were analyzed by an economic analysis of mangrove ecosystems based on direct use value that is expressed by Vo et al. (2012) where, for example, the direct use value of mangrove ecosystem is a human habitat. The existence of mangrove forests provides livelihoods for local communities and mangrove forest managers. The behavior of people around the mangrove forest was approached through an approach of economic household behavior and analyzed with productive activities that are related to mangrove resources, household revenue, working hours, household expenditures, and household surplus. 
The analysis of household production was done simply with the use of short-term analysis such as venture capital, business expenses, revenue, and profits. The analysis of household time outpouring was measured by the duration or time that is devoted to the activities of management and utilization of mangrove resources, time for other productive activities as well as its leisure time and domestic activities. The analysis of basic household expenses is calculated based on the basic expenses of food and non-food staple. Then, the difference of this household income and expenditure will be calculated with the household surplus.

\section{RESULTS AND DISCUSSION}

Coastal resources management in Cengkrong beach. POKMASWAS "Kejung has active members by 12 people whose help the team leaders in managing mangrove forests daily. In this study, the mangrove species which grow in an area of 83 hectares are: (1) Avicenna (api-api), (2) Sonneratia sp (Bogem or Pidada), (3) Burguera sp., (4) Ceriopstagal sp. (5) Lumnitcera racemose, (6) Rhizophora mucronate (Tinjang Panjang), and (7) Xyrocarpus s. Meanwhile, the ocean's creature that lives and can be cultivated by the people are (1) Mud crab (Scylla Serrata), (2) Anadara clam (Anadara sp.), (3) clam/scallop (Arctica Islandica).

Initial reforestation was carried out by the Department of Marine and Fisheries in 2008. Mangroves planting was then performed either independently by POKMASWAS "Kejung Samudra" or with the help of relevant agencies in 2009, 2010, and 2011. In 2009, mangroves planting in the types of waru and ketapang as many as 4,200 trees were established. Moreover, in the next year, the mangrove types of tinjang and nyamplung as many as 9,250 trees were also planted across the shore. Not only in 2010, replanting nyampung and tinjang mangroves by 37,500 trees were also carried out in 2011. The results of this replanting activity began to be noticed in Cengkrong coast with the sign of flourish mangrove forests. The concept of this mangrove ecotourism in Cengkrong is introduced by the Department of Fisheries and Marine of Trenggalek in 2012 with the construction of a wooden bridge over the mangrove.

Visitors in Cengkrong beach and mangrove forests keep on increasing especially during weekends and holidays. The ecotourism activities on Cengkrong beach and mangrove forests provide opportunities for forest managers which in this case is the board of POKMASWAS "Kejung Samudra" to open a kiosk as well as food and drink stalls in the entrance of the bridge as well as in the management of parking.

Household Economic Activities of Coastal Resource Users in Cengkrong Coast:

Productive activities in the mangrove ecosystem community. The resources of this ecosystem forest are utilized by the surrounding communities due to economic activity. The productive activities in Cengkrong are divided into two which are in the field of fisheries and non-fisheries. Fishery activities in this context were done by the administrators of POKMASWAS "Kejung Samudra" as well as fishermen and their wives also the surrounding community. Hence, some productive activities that are carried out by the communities in the mangrove surrounding area are as follow:

Mud crab cultivation (Scylla Serrata). The business of mud crab cultivation is done by POKMASWAS "Kejung Samudra" in which this crab could be found in the mangrove forest area. The business of this mud crab cultivation has begun in 2010 through the assistance of the Department of Marine and Fisheries of Trenggalek. The cultivation is also done with the help of karamba which is made of bamboo with an average size of $1 \times 0,5$ meter and then divided into several spaces that are intended for the maintenance of $20 \times 20,5 \mathrm{~cm}$ mud crab. The seeds of the crab are taken from mud crab that is obtained from mangrove forest which its size still does not meet the size of the market consumption. Moreover, the cage installation is placed in the mangrove area that is covered by tidal water while the feed of this mud crab is taken from the left-over fish that does not have an important economic value from fishermen. 
The capital investment that is used for this mud crab business is by IDR $1,545,000$ which includes buckets, bamboo, scales, rakes, and tarps. Then, the amount of the depreciation expense in one year is amounted up to IDR 532,500. Furthermore, the clear cost which is used for this business in one month is IDR 1,032,500 while the uncertain costs in one month are in the value of IDR 917,000. After that is about the income of this mud crab business which reaches IDR $10,800,000$ for one month with the profit of IDR $7,933,500$. This means that the rentability value obtained from mud crab business is by $276,77 \%$.

Mangrove plant germination. This germination activity has been done since 2011 . Some mangrove types which are germinated in this area are tinjang, Burguera, Sericarpus, Mentigi and Cemara Udang. The mangrove seeds which were planted are taken from the mangroves that have been grown in the area. Firstly, the germination is done by providing the seedbed media presented in a polybag. Then, the soil is mixed with manure and placed back in the polybag. After that, the germination process takes time for about 4-6 months. In the early germination activities in 2011, there were 35,000 mangrove plants which include 23,000 tinjang, 6,000 bogem, and 1,000 api-api. In the following year of 2012, there were also germination activities which consist of 20,000 tinjang, 1,500 Burguera, 1,000 Sericarpus, and 500 Mentigi. These mangrove seeds are marketed outside Cengkrong coastal areas, namely Panggul sub-district, Munjungan sub-district, and Trenggalek area. This mangrove seedling is sold for IDR 3000/trunk.

Mud crab farming. Not only farmed by POKMASWAS "Kejung Samudra" in an attempt of mud crab seed cultivation, the crabs also sought by local fishermen for mud crab farming. There are three respondents who usually look for crabs in the mangrove forest. There is also an asset or tool used by the farmers which are Bubu. Bubu is made to catch crabs and it is a kind of passive fishing gear, set and placed in areas that are expected to be passed by the crabs and baited with fish. Bubu framework is made of steel with some wood webbing and the price of this tool is IDR 28,000 to IDR 30,000 per unit with a lifespan of 2 years. The farming activities are carried out 2-3 times/week in which it usually sold to the market or to a seafood stall owner.

Per day, the average farming is amounted up to $2 \mathrm{~kg} /$ day/persons while the average total of this activity is $52 \mathrm{~kg} /$ month or $624 \mathrm{~kg} /$ year. Meanwhile, the commodity price of mud crabs which are sold to seafood restaurant is IDR 40,000/kg. Then, the average expenditure from the total cost is by IDR 2,283,333 which consists of depreciation cost by IDR 723,333 and variable cost by IDR $1,560,000$. The profit of mud crab farmers could be counted up to IDR 22,676,667 per person.

Fishermen. This fishing activity is established by a visitor or local communities to meet their daily needs or to fill their spare time on holiday. There are three respondents used in this research whose does not come from Cengkrong beach area. The calculated production assets in this activity are fishing gears as well as the calculated costs such as transportation fee and feed costs which are by IDR 12,000 per $0,25 \mathrm{~kg}$. The fishing activities are carried out from 10:00 am to 16:00 pm with the usual catch of Mugil Cephalus fish and Lutjanus sp fish.

The fishing is calculated on an average scale by $2 \mathrm{~kg} / \mathrm{week} /$ persons, thus, the total catch in one month is $16 \mathrm{~kg}$ or $192 \mathrm{~kg} /$ year with the average total cost of IDR 1,975,500/year. This includes a depreciation of fishing gear costs which amounted to IDR 103,500/year and the variable cost by IDR $1,872,000 / y e a r$. With the average price at fish collectors level is IDR $10,000 / \mathrm{kg}$, the total revenue of fish sales is IDR 1,920,000/year. Thus, the total income of the 3 crab farmers in mangrove area is amounted up to IDR 5,760,000 in a year.

Stalls managed by the wives of "Kejung Samudra" members. The stalls that are in mangrove tourist location are owned by five people. These people are the wives of the POKMASWAS "Kejung Samudra" members. The stalls in this area provide food, drinks, and coconut for the visitors. The production assets of this stalls include the building, refrigerator, storefront, and cool box. The price of one unit that is complete with its contents is valued for IDR 10.000.000 until IDR15,000,000 with a lifespan of 10 years. Each stall sells different types of food such as pecel, soto, and meatballs.

The effective time of this business is on Saturday, Sunday, and national holidays because visitors will be very crowded so that the sellers will receive a higher revenue. The 
average revenue on Monday to Friday is IDR 200,000 up to IDR 400,000 while on Saturday and Sunday there would be IDR 500,000 to IDR 2,000,000. The production costs of this business in every month amount to IDR 500,000 which include staples such as meat for meatballs, soup, spices, and of course, coconut.

The average income of these businesses is by IDR $65,544,000 / y e a r$ with the average total production cost of IDR 19,314,000/year. This consists of the average cost of stalls depreciation by IDR 3,252,000/year and the average variable cost by IDR 16,062,000/year. Thus, the average revenue from this business could be amounted up to IDR $46,230,000 /$ year with the profit of IDR 9,246,000/year/person.

Parking management. The location of this mangrove conservation provides a $20 \times 80 \mathrm{~m}^{2}$ parking area. In details, one tariff for a motorcycle is IDR 5,000 while one car is IDR 10,000. The revenue that could be obtained from Monday to Friday is ranged from IDR 200,000 to IDR 400,000 while on Saturday and Sunday or holidays can be IDR 1,000,000 - IDR $2,000,000$. Therefore, the sharing system of the parking lot is $10 \%$ of total revenue. The income for the workers is given by the chairman of "Kejung Samudra" once in every 2 weeks based on the duties of each board.

Boat Rental. This boat rental is operated by two members of POKMASWAS, however, the boat rental activity is adapted to the tide condition. When the water is in low-tide, the boat cannot be rented. The production assets from this boat business are boats and engines. The price of one unit of a boat is set in IDR $15,000,000$ with a lifespan of 10 years while the price of the machine is IDR 5,000,000 also with a lifespan of 10 years. The type of machine that is used is a 2-stroke engine. Furthermore, the operational cost which is used in this business is as much as 5 liters of fuel for one operation (one day) at a unit price of IDR 7,500 and 0,5 liters of oil for one operation. The rates which are charged to visitors is by IDR 10,000 /person. According to that, the average income of this business is between IDR 250,000 to IDR 500,000 on Sundays or holidays. The worker's payment of this business is also $10 \%$ of the total revenues and given once in every 2 weeks.

Sanitary facility. The provision of public toilets is very helpful for the visitors; there are 6 units of bathrooms or toilets provided. The charge for this sanitary facility is divided into three such as IDR 5,000 for a shower, IDR 3,000 for defecate, and IDR 2,000 for urination. The income of this sanitary facility on Monday to Friday is between IDR 200,000 until IDR 300,000 while on Sunday is between IDR 500,000 to IDR $1,000,000$. The worker's division is also based on the determined guard shifts with the income of $10 \%$ of the total revenue and given once in every 2 weeks.

Sellers in beachside. There are sellers in the beachside started to sell their goods since the existence of this ecotourism forest. They do their activities only on Saturday and Sunday in which they sell smoked fish, squid, and also crab. Besides that, they also sell drinks, coffee, rice, and coconut. Smoked fish is sold at a price of IDR 5,000/skewer, chicken rice by IDR 7,000/portion, coffee for IDR 2,000/glass, coconut at a price of IDR 8,000, and then squid and crab in each by IDR $40,000 / \mathrm{kg}$.

The production assets of this business are the semi-permanent stalls located on the beach, carts, as well as the cost of fishing that is used to catch crabs and squid. The revenue that is generated from this business is ranged from IDR 500,000 up to IDR $1,500,000$ depends on holidays and the number of visitors. The average income of this business is IDR $30,240,000 / y e a r$ with the average total cost by IDR $7,723,333$. This includes the average fixed cost by IDR 743,333 and the variable cost by IDR $6,980,000$. On average, the profit that is enjoyed by the beachside sellers is IDR 7,505,555/year/person.

Farmers. From 19 respondents, there are 6 respondents who have a farm with an extensive of 0,25 ha to 1,5 ha. Farming activity is a side job for them, this is a business that starts from a forest clearing on Karanggandu area. The types of the crops grown in this area are coconut, cloves, durian, and jengkol. Durian and jengkol are classified as an annual plant while cloves can only be harvested after 3 years and after that, cloves can be harvested twice a year. The average revenue from this farming activity is IDR 3,394,000/year. Durian could be sold for IDR 25,000/fruit, wet cloves could be sold for IDR 31,000/kg whereas dried cloves are IDR 41,000, and lastly, jengko/ which is by IDR 5,000/kg. 
Fisheries and Non-Fisheries Working Time of the mangrove resource users in Cengkrong Beach. The activity of mangrove reforestation in Cengkrong Beach provides a job development for the communities around the coast. In this following section, the work outpouring of mangrove resource users will be presented. The work outpouring is determined by using a workdays unit (Hari Orang Kerja or HOK), where $1 \mathrm{HOK}$ is equal to 8 hours per day. The HOK that is used by the households in mangrove forest area either in fisheries or non-fisheries activities is calculated in a unit per year to equalize the unit counted.

"Kejung Samudra" Members. The daily activities of "Kejung Samudra" members are managing mangrove forests, treating and monitoring mangrove growth, providing mangrove seeds, and managing the businesses such as boat rentals, motorcycle or car parking lot, and toilet or bathroom facility. This activity is performed daily starting at $09.00 \mathrm{AM}$ in the morning until $17.00 \mathrm{pm}$ while there is 1 hour for a break (lunch and pray). However, this is in contrast with the boat rentals which this business is depending on the sea tide. The division of labor time is divided by shifts so that the average work time is $4-8$ hours/day. The total work outpouring of the "Kejung Samudra" member is full for one month and the average working time is $315 \mathrm{HOK}$.

Crab Farmers. Mud crab fishing activity is carried out during high tides so that the water will cover large areas of mangrove forests. Even though after the water is receded, some water still puddled in the area. Thus, during this low tide, crab farmers start looking for crabs among the crevices of sand and mangroves. Nevertheless, this activity is not implemented every day but only when there is high tide. Within a week, the high tides will occur 2 to 3 times. This crab fishing activity is carried out from $15.30 \mathrm{pm}$ to $17.30 \mathrm{pm}$ and with the help of crab fishing gear installation. Meanwhile, the Bubu tools are released in the next day at $05.00 \mathrm{pm}$ until $07.00 \mathrm{pm}$, thus, the average result of this crab fishing in one year is by $72 \mathrm{HOK} /$ person/year.

Fishermen. Fishing activity is only done on Saturday and Sunday from 10.00 am to $16.00 \mathrm{pm}$. In one month, this fishing activity could be performed 8 times by 3 respondents. By that, the average fishing activity that is carried out amounts to $72 \mathrm{HOK} /$ person/year.

Stalls Owner in Parking Area. The average time that is spent on the stalls on Saturday, Sunday, and national holidays are 8-9 hours per day, from 09.00 am until $17.00 \mathrm{pm}$ while the typical working day is about 6-7 hours per day. This makes the average working time devoted by the shop owner in a month by 192 hours. So, this can be said that the average time of the wives working in a stall is by 2520 hours/year or 315 HOK.

Sellers in Beachside. These selling activities are performed on Saturday and Sunday in the beachside. The duration of this activity is also depended on the visitors. This usually started at $09.00 \mathrm{am}$ to $17.00 \mathrm{pm}$ in which it makes the workers work 7-8 hours/day. Thus, the sellers in the beachside are likely to run its business in a month by 61 hours/month or 7,6 HOK/month.

Farm Activity. The activities that are carried out outside the fishing activity is field cultivation in the forest. The people tend to cultivate its farm or do the cultivation thing after their fishery activities have done. This activity is a side activity, they are not always doing this kind of job every day. In farming, the time that is spent in this occupation is approximately counted for 4-5 hours/day with the average of 1-2 times a week. The time that is spent for harvesting is determined by the type and number of trees; tree species are different if it comes to harvesting. For an instance, the harvest process of clove takes about 6-7 hours, while palm tree only takes 3 hours per harvest. In a year, an average time for harvest is amounted up to 730 hours/year or 91 person/days/year.

Household Income of the mangrove resource users in Cengkrong Beach. Household income in this community covers the income of "Kejung Samudra" members, crab farmers, sellers, and fishermen. This revenue is calculated by merging the income from fisheries and non-fisheries activity. The household income is grouped into several classes to know the level, interval, and the highest and lowest household income as presented in Table 1 below.

Based on the data that is presented in Table 1 above, it can be concluded that the biggest number of the respondent is as many as 11 respondents with the interval revenue of IDR $15,673,120$ - IDR $26,954,576$ while there is only 1 respondent with the income of IDR 
$67,547,488$ - IDR $87,828,944$. Furthermore, the highest value of household income is IDR $108,090,400$ while the lowest value is IDR $15,683,120$ with the average value of household income by IDR $35,876,390$.

Table 1 - The Scale of Household Income

\begin{tabular}{|c|c|c|}
\hline Class & Interval (IDR/year) & Total (house) \\
\hline 1 & $15.673 .120-26.954 .576$ & 11 \\
\hline 2 & $26.964 .576-47.246 .032$ & 2 \\
\hline 3 & $47.256 .032-67.537 .488$ & 1 \\
\hline 4 & $67.547 .488-87.828 .944$ & 2 \\
\hline 5 & $87.838 .944-108.120 .400$ & $108,090,400$ \\
& Max & $15,673,120$ \\
& Min & $35,876,390$ \\
\hline
\end{tabular}

Household Outcome of the mangrove resource users in Cengkrong Beach. Household expenditure is divided into 2 groups such as food staple expenditure and non-food staple expenditure. The total household expenditure is the total expenditure of the fisherman that spends its money on non-food staple and food staple. The spending in food staple is all the expenditure that is used for domestic consumption such as rice, corn, tubers, tofu, tempeh, animal protein (fish and egg), vegetables, cooking oil, sugar, coffee, and others. Meanwhile, the non-food staple expenditure is the outcome on electricity, clothing, health, education, expenses for social events, and other expenses.

The consumption of food staple in mangrove household community is rice. In this area, rice consumption in a week is approximately $7 \mathrm{~kg} /$ week, this actually depends on the number of family members that consumed rice and also influenced by diet program. Occasionally, the people also consume tempeh or tofu even though it was not necessarily once a week. Whereas, tofu or tempeh is sold for IDR 2000/piece. The side dishes which are often consumed by the people in this area are fish which include tuna, crab, squid, surut, and so forth. In addition to fish, the people in the community also consume chicken eggs. The majority of respondents do not consume meat, they tend more on fish.

Almost every day, respondents also consumed vegetables such as kale, spinach, papaya, cabbage, young jackfruit (tewel), carrots, beans, eggplant, and so forth. For vegetables, they sometimes do not need to buy because they also grow their own vegetables or just go seeking in the woods. People in this area, in average, use cooking oil for as much as 1 liters of cooking oil/week and sugar $0,5 \mathrm{~kg} /$ week to $1 \mathrm{~kg} /$ week. They also like to consume coffee in which it requires IDR 3,500/pack but some respondents would prefer to make their own coffee that is made from coffee plants around the respondent's house. The need of food is normally purchased at a store near the houses which is approximately at a distance of $100 \mathrm{~m}$ while shop owners usually take on its goods itself.

The total average household expenditure in mangrove area amounts to IDR $14,712,263$ within one year. Furthermore, the average expenditure on food staple is by IDR $10,083,571$ and non-food staple by IDR 3,722,842. The highest non-food expenditure for the people is on education expenses which amounted up to IDR 9,000,000/per year and then

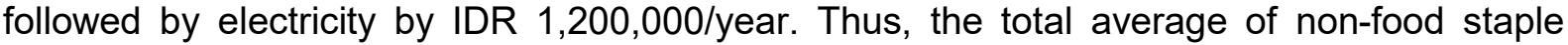
expenditure is IDR 3,722,842. Based on the type of work, the highest spending on non-food staple is obtained by "Kejung Samudra" member among other types of employment by IDR $46,915,000 / y e a r$. The size of the non-food expenditure is largely influenced by the number of family members, especially family members who attend school. Table 2 below presents the scale of household outcome in coastal communities.

The most household outcome of mangrove user communities is shown at the interval of IDR 10,445,000/year to IDR 12,945,000/year. The 2nd largest expenditure in one year is at the interval of IDR $12,955,000$ to IDR $21,445,000$ which is experienced by 5 respondents. The highest total household outcome in one year is IDR 46,915,000 while the lowest is IDR $10,465,000$ with average household expenditures both from food staple and non-food staple by IDR 14,712,263/year. 
Table 2 - The Scale of Household Outcome

\begin{tabular}{|c|c|c|}
\hline Class & Interval (IDR/year) & Total (house) \\
\hline 1 & $10.445 .000-12.945 .000$ & 11 \\
\hline 2 & $12.955 .000-21.445 .000$ & 1 \\
\hline 3 & $21.455 .000-29.945 .000$ & 1 \\
\hline 4 & $29.955 .000-38.445 .000$ & 1 \\
\hline 5 & $38.455 .000-46.945 .000$ & $46,915,000$ \\
& Max & $10,465,000$ \\
& Min & $14,712,263$ \\
\hline
\end{tabular}

Household Surplus. The surplus is the difference between total household income and household outcome. The household surplus is usually used as a savings or also for the purchase of production assets. The highest income surplus is the chairman of "Kejung

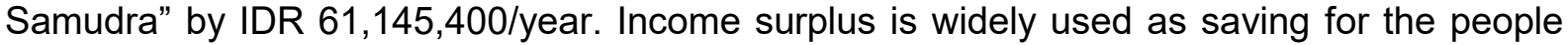
and their savings are usually in the form of gold or jewelry. This can be seen from the people which many of the wives use gold as their jewelry. The reason why they keep the savings in the form of jewelry because it is easy to be sold at any time in case of sudden needs.

\section{CONCLUSION}

The reforestation of mangrove forests in the coastal region of Cengkrong under POKMASWAS "Kejung Samudra" has been well managed. The dominant tree species which grow in Cengkrong coastal area are three types, namely: Soneratia Alba, Avecienna sp, and Bruguiera sp. The results of the reforestation could provide such household economic activities of local communities, especially for POKMASWAS "Kejung Samudra" manager.

The economic activity of mangrove forest management that is carried out by the administrators of POKMASWAS "Kejung Samudra" includes mud crab cultivation, mangrove seeds germination, parking management, boat rental, sanitary facility, and food stalls. Meanwhile, the economic activity that is conducted around the mangrove forests covers crab farming, fishing, and trading.

The work time for productive activities of the people in the community is quite enough. The average household still has time for leisure activities. Furthermore, the income of their activities may be used for household expenses and even create a household surplus.

\section{SUGGESTION}

The results showed that the reforestation and management of mangrove ecosystems can provide opportunities for economic activities in the surrounding communities that is related to tourism activities. Therefore, (1) the management of mangrove that takes into account of conservation needs to be done continuously (2) the development of other businesses that utilize the results of mangrove plants such as leaves and fruit needs to be introduced and developed due to the mangrove plant that grows on Cengkrong is already quite diverse.

\section{REFERENCES}

1. Susilo, E., Hidayat, K., Syafa'at, R., Musa, M. and Purwanti, P. (2008). Daya Adaptasi dan Jaminan Sosial Masyarakat dalam Rangka Mencapai Ketahanan Pangan Domestik (Dinamika Kelembagaan Lokal Pengelola Sumberdaya Perikanan Kawasan Pesisir) IRD Research Report. Ministry of Research and Technology, Indonesia.

2. Eleanya. K., Agbeja, B.O. and ljeomah, H.M. (2015). Socio-Economic Importance of Mangrove Forests In Akassa Island of Niger Delta, Nigeria. PAT Journal, 1 (11): 1-11.

3. Van Hue, L.T. and Scott, S. (2008). Coastal Livelihood Transitions: Socio-economic consequences of changing mangrove Forest management and Land Allocation in a 
Commune of Central Vietnam. Journal compilation Institute of Australian Geographers. Geographical Research, 46 (1): 62- 73.

4. Nasir, M. (2003). Metode Penelitian. Ghalia Indonesia, Bogor.

5. Saint-Paul, U. (2006). Interelations among mangroves, The local economy and social sustainability: a review from a case study in North Brazil. CAB International. Environment and Livelihood in Tropical Coastal Zones.

6. Vo, Q.T., Kuenzer, C., Vo, Q.M., Moder, F. And Oppelt, N. (2012). Review of valuation methods for mangrove ecosystem service. Ecological Indicator, 23: 431-446. 